\title{
Den kirkelige sproggrænse
}

\author{
Af Troels Fink.
}

(Foredrag holdt ved Historisk Samfunds ârsmøde 27. maj 1956)

Det er en kendt sag, at den nuværende grænse mellem Danmark og Tyskland omtrent svarer til den kirkelige sproggrænse, der efter reformationstiden blev draget tværs igennem hertugdømmet Slesvig. Luthers store princip om, at gudstjenesten skulle holdes på modersmålet, blev kun delvis virkeliggjort, for grænsen mellem det danske og det plattyske folkesprog gik på reformationstiden langt længere mod syd end den nuværende statsgrænse. Hele Angel var dansktalende, $\mathrm{i}$ midtlandet gik grænsen langs Danevirke henimod Husum og drejede derfra nord på uden om det frisiske område, der strakte sig til sognene syd for Tønder.

I den første tid efter reformationen var forholdene ret flydende. Den kirkelige sproggrænse lå ikke fast. En vis fastlæggelse fandt først sted i løbet af det 17 'ende århundrede; kirkesproget blev bestemmende for skolesproget, men skolegangen var ikke særlig effektiv før det $19^{\prime}$ ende århundrede, og først da fik dette kulturskel sin endelige og afgørende betydning.

Med disse forhold givne, - det danske folkesprogs faktiske udbredelse, det lutherske princip om modersmålets anvendelse i kirken og med den kirkelige sproggrænse draget tværs igennem det dansktalende område i Sønderjylland, bliver spørgsmålet så, hvorfor denne uoverensstemmelse? Hvorfor blev Luthers tanke ikke gennemført med samme konsekvens her som andet steds. Det havde dog efter en almindelig opfattelse været så naturligt, at folkesproget blev det grundlæggende, og kirkesproget indrettet derefter.

Når man står over for dette problem, må man billigvis erkende, at plattysk havde en stor udbredelse $i$ Slesvig allerede $i$ middelalderen, dels var plattysk talesprog $i$ det sydligste bælte, egnen mellem Danevirke og Ejder og Eckernførde og Levenså og dels 
var tysk sprog ved at erobre halvøen Svansen, og det var udbredt i de sønderjyske købstæder. I Slesvig by var det danske sprog fortrængt allerede i højmiddelalderen, og i Flensborg blev plattysk mellem 1300 og 1400 forretningssproget, medens talesproget har været et slemt blandingssprog. Humanisten Christiern Petersen, der især er kendt, fordi han reddede Saxos værk for eftertiden, skrev i 1531 med foragt om det "Flensborgis danske“, „thi man taler der danske og tyske tilhobe“, siger han, og i de nordslesvigske købstæder var plattysk ligeledes anvendt som forretningssprog, købmændenes og administrationens sprog, men omgangssproget var dansk. Endelig má man nævne, at den dominerende overklasse, herremændene $i$ hovedsagen, betjente sig af plattysk og i de sydlige egne af landsdelen udelukkende af dette sprog.

Men spørgsmålet bliver alligevel tilbage, hvorfor kom grænsen til at gå netop fra Tønder til Flensborg, hvorfor ikke sydligere eller nordligere? Hvorfor kom blandingsbæltet oprindelig netop her? Der er forskellige muligheder for at søge en forklaring, men fyldestgørende lader forholdet sig ikke oplyse; kilderne er ikke tilstrækkelige. På grundlag af mange spredte oplysninger må man gøre sig sine hypotetiske overvejelser.

Først vil det være naturligt at undersøge, om der var et gammelt administrativt skel, der delte Sønderjylland i et Nord- og Sydslesvig. Det var der ikke. Det sproglige blandingsbælte fordeler sig over to amter, Flensborg amt $\mathrm{i}$ øst og Tønder amt $\mathrm{i}$ vest, og grænsen kom til at gå midt igennem disse to amter. Man kan således ikke tænke sig noget øvrighedsbud, der havde fastsat grænsen i overensstemmelse med bestående administrative inddelinger, for heller ikke herredsgrænserne hjælper. Der var overgangsforhold i Husby herred, i Vis herred, i Kær og Slogs herred og i Tønder herred. Mod ost fik Vis herred efterhånden tysk kirkesprog. Mod vest kom siden skellet til at gå mellem Slogs herred i nord og Kær herred i syd, men på reformationstiden og i lang tid derefter var grænserne ikke skarpe.

Man kan så gå videre og undersøge den kirkelige administrations grænser. Det kunne jo tænkes, at et gammelt skel fra den katolske tid kunne spores; en kortfattet oversigt over den kirkelige inddeling vil vise, at problemet om den kirkelige sproggrænse heller ikke kan finde sin løsning ad denne vej. 


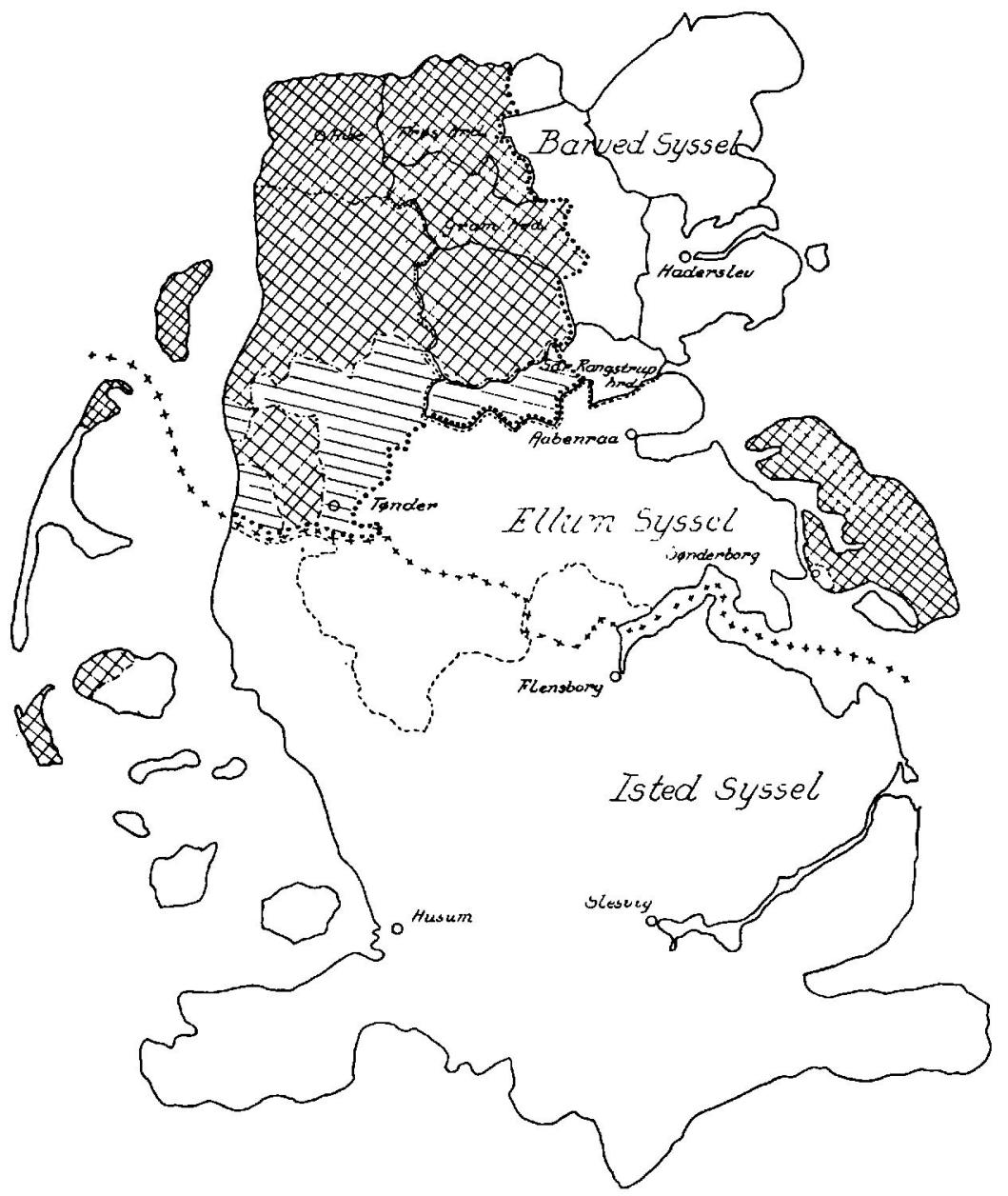

Inder Ribe stift for reformationen.

Under Ribe og Odense stifter efter reformationen.

++++ Skelbakgransen 1920 .

- $\ldots$ - Sysselgraenser.

Herredsgranser.

Stifts- og sysselgrænser i Sønderjylland. 
Da stiftsinddelingen blev gennemført i Jylland på Svend Estridsens tid i 2. halvdel af det 11. årh., fulgte man som helhed de gamle sysselgrænser, to eller tre sysler blev sammenlagt til et stift, men i Sønderjylland gik det anderledes. Af de tre sønderjyske sysler Isted, Ellum og Barvid kom kun Isted syssel som en helhed under Slesvig stift, mens et stort hjørne af Barvid og Ellum sysler blev lagt under Ribe stift. Hele Kalvslund, Hviding, Lø, Tønder, Højer og Nørre Rangstrup herreder, størstedelen af Frøs, og ligeledes en stor del af Sønder Rangstrup herred samt lidt af Gram herred kom under Ribe-bispen. Det er besynderligt, at stiftsgrænserne end ikke fulgte herredsgrænserne. Det ser ud til, at grænsen er draget ved et kompromis. Muligvis har der været en uoverensstemmelse mellem Slesvig- og Ribe-bisperne. Det område, der kom til Ribe, kan traditionelt have været knyttet til dette bispesæde, før stiftsinddelingen blev endelig. Af Frøs herred kom Skodborg sogn til Slesvig stift, resten til Ribe. Gennem Skodborg passerede hærvejen, og Hugo Matthiessen mener, at Slesvig-bispen har villet sikre sig den fulde kontrol med den vigtige færdselsåre, en mulighed, der ikke kan afvises. Man kan måske også øjne en slags demonstration fra Slesvig-bispens side, når det nordøstligste provsti med centrum i Haderslev blev kaldt „provstiet Barvid-syssel", al den stund det kun var den østlige del af det gamle Barved-syssel, der kom under provstiet. (Provstiet omfattede området mellem Kolding fjord og Genner fjord). Syd derfor lå provstiet Ellum-syssel; det var også kun en del af dette syssel, der hørte under Slesvig-bispen. 5 af syslets 10 herreder havde Slesvig-bispen og 5 havde Ribe-bispen. Men alligevel kaldtes provstiet Ellum-syssel. Spændingen mellem Slesvig og Ribe er i sig selv et interessant fænomen, men hvad her er anført, skal blot belyse det faktum, at den katolske inddeling ikke giver nogen forklaring på sproggrænseproblemet.

På reformationstiden gik den gamle kirkelige inddeling for en stund helt i opløsning. Christian III havde, før han blev konge, af sin far fået overdraget administrationen af det nuværende Haderslev amt, både den østlige del, der i overvejende grad hørte under Slesvig-bispen, og den vestlige del, Tørninglen, der horte under Ribe-bispen. Han gennemførte her på egen hånd sidst i 1520 'erne reformationen. Haderslev amt blev organiseret som et 
lille stift med en superintendent, et nyt navn for en biskop, og en provst $i$ hvert herred. Superintendenten var tysk og kunne ikke stå i umiddelbar kontakt med de dansktalende præster. Herredsprovsterne var mellemmænd mellem ham og præsterne. Fra 1528 stammer et udkast til en kirkeordinans, hvori bl. a. bestemmes, at litaniet i Haderslev amt skal synges på dansk, og børn døbes på dansk. Der må være tænkt på dansk i modsætning til latin, for prædikensproget bliver ikke specielt omtalt; det var som en selvfølge dansk; allerede $i$ den katolske tid havde der været prædiket på modersmålet. Hvad prædikenerne angik, kunne man sâledes fortsætte i det gamle spor.

Fra 1533 til 36, mens Christian III var optaget af kampen om magten i Danmark (Grevens Fejde), gik tingene på bedste beskub, men fra 1536 kunne kongen for alvor tænke på at gennemføre reformationen i Danmark. Officielt regner man med, at reformationen fandt sted i 1536, men i Sønderjylland trak sagen i langdrag. I 1538 blev hertugdømmet - for de protestantiske gejstliges vedkommende - inddelt i 5 små kirkelige enheder, men endnu sad den katolske biskop i Slesvig Godske Ahlefeldt. Det ser ud til, at generalsuperintendenten i Haderslev havde det meste af det nuværende Nordslesvig under sig; grænserne er dog ikke helt klare, men man tor regne med, at den kirkeskik, der havde fæstnet sig i Haderslev, nu fik mulighed for at brede sig til de øvrige nordslesvigske egne. Vi kan derved danne os en forestilling om, hvordan forholdene blev ordnet i Nordslesvig i almindelighed, men vi får stadig ikke nogen forklaring på grænselinierne som sådanne, for der var sogne, som hørte under superintendenten i Flensborg, som fik dansk kirkesprog, og forholdene ved Tønder er meget uklare.

I 1542 døde Godske Ahlefeldt, og i samme år fik Sønderjylland sammen med Holsten en ny kirkeordinans, og derved blev reformationen fuldbyrdet. En protestantisk biskop blev indsat, ensartede regler blev gennemført. De små superintendenter fra 1538 mistede deres beføjelser. I Haderslev amt bibeholdtes herredsprovsterne, mens der $\mathrm{i}$ de øvrige amter kom amtsprovster. Ribe fik 1543 Tørninglen tilbage, men adskillige sogne i Tønder amt og enkelte i Åbenrå amt blev løsrevet fra den gamle forbindelse med Ribe. 
I 1544 blev Sønderjylland delt mellem kongen Christian III af hans to brødre. Hans den Eldre fik Haderslev og Tønder amter, mens Åbenrå amt sammen med Slesvig kom under Gottorper-hertugen Adolf, og Flensborg-Bredsted amter og dertil AlsSundeved kom under kongen. Der kom senere nye politiske delinger, men hverken den i 1544 eller de senere fik umiddelbar betydning for kirkesproggrænsen. Hertug Hans den Eldres område havde et sprogligt blandingsbælte i Tønder amt. Kongens område havde et blandingsbælte i Flensborg amt, mens det gottorpske Åbenrå amt i modsætning til Slesvig og Husum amter havde dansk kirkesprog. Man tør af alt det her anførte slutte, at den kirkelige sproggrænse ikke var et problem for de styrende. Resultatet kan opgores således: Haderslev og Ảbenrå amter var rent danske, Tønder amt overvejende, men med blanding i det sydligste geestherred, Kær herred. Marskherrederne, d.v. s. de frisiske områder, ser vi her bort fra, her var tysk fremherskende. Gottorp amt var sandsynligvis helt tysk og Flensborg amt stærkt blandet.

Som man kan regne med, at der ikke har foreligget noget bud ovenfra, tør man også gå ud fra, at menigmand kun kunne ove ringe indflydelse på kirkens forhold. Tilbage bliver så som den egentlige afgørende præsten selv, der må have haft et ret stort ord at sige ved valg af kirkesprog $\mathrm{i}$ de områder, hvor der ikke var overensstemmelse mellem sproget i kirken og det sprog, den jævne mand talte, altså $\mathrm{i}$ det ret store mellemslesvigske område, hvor den danske dialekt var fremherskende.

De forskere, der fortrinsvis har beskæftiget sig med denne tid, er frøken Johanne Skovgaard og dr. theol. Hejselbjerg Paulsen. De repræsenterer hver sin afvigende vurdering. Frk. Skovgaard, der har skrevet afsnittene om denne tid i den store Sønderjyllands historie, mener, at præsterne på landet i Slesvig i hovedsagen var hjemmehørende. De få tilfælde, der kan oplyses for Sydslesvigs vedkommende, tyder også på, at landsbypræster var egnens burn. Hun siger om dem: „Præsterne selv var for det store flertals vedkommende tyskdannede allerede fra latinskolen og studietiden ved tyske universiteter, og den ny tids tanker, som ofte greb sindet med overvældende magt, kom kun til de unge, iklædt tysk dragt. Også den honette ambition, der fra købstaden med dens tvesprogede overklasse bredte sig til landet, virkede til fordel for brugen 
af tysk. Ikke des mindre er og bliver det vanskeligt at forklare, at så mange sønderjyske præster ikke brugte deres og menighedens fælles modersmål som gudstjenestens sprog “. ${ }^{1}$

Dr. Hejselbjerg Paulsen siger i sin skildring „Fra Skolebænk til Prædikestol“ om Sydslesvig: „Alt flød og var i bevægelse i 1530'erne og $1540^{\circ} \mathrm{erne}$, og der er sogne, hvor præsterne synes at have skiftet fra år til andet, når der åbnede sig nye og bedre udsigter. Embedsjægerne fandt vej ud $i$ alle landsogne, efter at andre embeder var optagne... De må have talt tysk, thi dansk kunde de ikke, og de agtede vel heller ikke at lære det. Det er vel den eneste forklaring på, at Sydslesvig - og senere også Mellemslesvig fik tysk kirkesprog." 2 Dr. Hejselbjerg Paulsen lægger altså mere vægt på de indvandrede tyskfødte præster i Sydslesvig, så vidt de sparsomme kilder tillader os nogen slutninger.

Ved siden af disse forsøg pâ at give en forklaring på den kirkelige sproggrænse skulle der her opstilles en lidt anderledes formuleret hypotese til nærmere overvejelse, nemlig den, at prædikesproget blev bestemt af præsten selv, ikke vilkårligt, men $i$ overensstemmelse med det sprog, han havde lært ved siden af latin under sin uddannelse, d.v.s. prædikensproget er afhængigt af, om han havde lært sin latin ved at få det forklaret på dansk eller på plattysk, altså ikke så meget de afsluttende universitetsstudier, men den grundlæggende skolegang. Man regner med, at de fleste præster på reformationstiden gik over til den ny lære og fulgte parolen om at prædike evangeliet på modersmålet. En del nye er desuden kommet til, men hvor præsterne end er kommet fra, har de, hvis ellers hypotesen kan holde, så vidt muligt prædiket $\mathrm{i}$ det sprog, der i skoletiden havde været det folkelige grundsprog ved siden af latin. Man har næppe lært latin umiddelbart på grundlag af landsdelens dialekt. Dansk skriftsprog eller plattysk skriftsprog må have været benyttet ved tilegnelsen af latin. Disse to folkelige skriftsprog blev i den følgende tid hårdt trængt af højtysk.

I hvor høj grad kan man nu sandsynliggøre denne påstand? Går man ud fra, at flertallet af præsterne er blevet $i$ deres embeder, - man ved, at det var tilfældet i Haderslev amt - , bliver det nødvendigt at se lidt på præsteuddannelsen i hertugdømmet i Slesvig lige før reformationen. I parentes skal det her bemærkes, 
at prædikenen for menigheden også indgik som et led i den katolske gudstjeneste før reformationen, følgelig kan problemet om den kirkelige sproggrænse godt være ældre end reformationen; en kirkesprogstradition kan godt have fæstnet sig i senmiddelalderen, men det er en slutning, der ikke lader sig verificere.

Præsteuddannelsen var i den katolske tid organiseret således, at der ved hver domkirke under domkapitlet fandtes en præsteskole, der gav den almene uddannelse. Den grundlæggende skolegang kunne også ske andre steder end $i$ stiftsbyerne; der var latinskoler i flere købstæder, men det var et alment krav, at de vordende præster efter overstået grundlæggende undervisning skulle tjene to år som korvikarer i stiftets domkirke, før de kunne befordres til noget embede. Det er det almene billede. Efter dette skema skulle altså vordende præster i Slesvig stift uddannes ved domskolen i Slesvig by; alsingere skulle gå til Odense og nordvestslesvigere til Ribe, men for den nordlige del af Slesvig stift var der en undtagelse. I Haderslev fandtes det såkaldte kollegiatkapitel, der i sin opbygning svarede til et domkapitel. Det bestod af præster og kanniker. - Dette kollegiatkapitel fik efterhånden ligeret med domkapitlet i Slesvig med hensyn til at uddanne præster, og det blev bestemt, at unge gejstlige, der var født $i$ provstiet Barved-syssel (Haderslev provsti), kunne gøre deres korvikartjeneste i Haderslev. At grundsproget i kollegiatkapitlet i Haderslev har været dansk, må anses som det sandsynligste, men adskillige tyske prælater havde efterhånden fået tilknytning til kollegiatkapitlet i Haderslev. Dog ved man, at der i den katolske tid også holdtes prædiken på modersmålet; i 1442 blev en lektor ansat med denne opgave. Den latinske formulering lyder: „ut vicarius singulis diebus Apostolorum et maioribus festiuitatibus ac dominicis populo vulgariter in loco congruo in eccelesia aut in Ambitu Hadersleuensi predicet $\ll$.

Folkesproget kan her næppe være andet end dansk. Der har dog også i Haderslev været gejstlige med nedertysk modersmål.4

For Haderslev provstis vedkommende synes forholdet at være klart nok i den katolske tid; anderledes for den øvrige del af Nordslesvig, d.v.s. i provstiet Ellum-syssel, der dækkede den slesvigske biskops del af Ảbenrå og Tønder amter. Efter al sandsynlighed har der også her været mindre skoler, hvor vordende præster 
kunne få en fordannelse. Muligvis har Kliplev haft en skole. Der foregik også oplæring i klostrene, f. eks. Løgumkloster (under Ribe stift), hvor det danske sprog var klart fremherskende; de unge fra den del af Nordslesvig, der ikke hørte til Haderslev provsti, havde altså også andre steder at gå hen, men med hensyn til korvikartjenesten var regelen, at de skulle gå til Slesvig; om de så har gjort det alle, kan vi ingen viden have om.

Da reformationen begyndte i 1520'erne, var Haderslev den nye læres brændpunkt; det havde betydning ikke alene for Sønderjylland, men for hele Danmark. Om de to skåninger Claus Mortensen Tøndebinder og Hans Olufsen Spandemager hedder det i en gammel katolsk krønike om deres ophold i Haderslev: „Her lærte de danske viser og det lutheriske kætteries gift". Ordet "viser" skal nok forstås som "salmer“. Fra 1527 til 1537 har præsteskolen i Haderslev været af stor betydning, fordi dens opgave netop var at omstøbe reformationen $i$ dansk form. Reformationen kom som helhed sydfra, men dens udbredelse i Nordslesvig udstrålede fra Haderslev i dansk oversættelse. Den nye læres gennembrud i Sydslesvig må derimod ses i umiddelbar forbindelse med den brede reformatoriske strøm fra Tyskland.

Man må formode, at foruden tilvandrede præster, som dr. Hejselbjerg Paulsen har nævnt, også de præster, der var født i Slesvig stift, og som havde fảet deres undervisning $i$ latin med plattysk som grundsprog, og derefter tjente i Slesvig domkapitel i den katolske tid, at disse præster også i dansktalende egne af Sydslesvig har brugt plattysk, så langt det lod sig gøre, fordi de simpelthen aldrig havde forbindelse med nogen form for dansk kultursprog. Et vist kendskab til plattysk, som var handelssprog og administrationens sprog, må nok forudsættes hos den mandlige befolkning i store dele af Sydslesvig. For en præst, der aldrig under sin uddannelse havde mødt det danske skriftsprog, måtte det være en meget vanskelig ting at skulle prædike på dansk. Hvis det var en af egnens folk, kunne han i den daglige omgang hjælpe sig med dialekten og forklare visse begreber, men det måtte blive en praktisk hjælpeforanstaltning.

Det forhold, at den kirkelige sproggrænse i den første tid efter reformationen var flydende, passer godt med hypotesen om, at præsterne selv har valgt prædikensproget efter deres personlige 
forudsætninger. Der er f. eks. vidnesbyrd om dansk prædiken adskillige steder i Sydslesvig, hvor tysk prædikensprog senere vandt hævd. Det gælder Husby og Esgris i Angel, Kværn indtil 1570, Grundtofte til ca. 1572, ligeledes Hanved sogn i Vis herred indtil 1661, medens man ved, at andre sogne med samme vilkår, f. eks. Havetoft, Gelting og Eggebæk havde plattysk kirkesprog. Fra ca. 1640 forsvandt det danske helt i Angel. Det kan også ses, at der i et enkelt nordslesvigsk sogn, Højst, en tid har været prædiket på tysk. ${ }^{5}$

I løbet af det første århundrede efter reformationen vandt plattysk sprog frem i den dansktalende del af Sydslesvig. Hermed er vi inde på et andet betydningsfuldt problemkompleks, der her blot skal antydes. De spredte steder, hvor dansk havde fundet anvendelse af enkelte præster med danske forudsætninger, skabte ikke her tradition. Udligningen skete i tysk favor; alle forhold arbejdede det tyske sprog $\mathrm{i}$ hænde, bibel, salmesang, liturgi og agenda. Når en ny præst uden blot de ringeste danske forudsætninger kom til et sogn, lod det sig gore at afskaffe det danske prædikensprog. Men samtidig var en ny bølge sydfra på vej for at indhente og fortrænge det plattyske sprog. Fra ca. 1600 trængte det højtyske sprog frem. I den del af Sønderjylland, som det her især kommer an på, i Flensborg amt, var det i midten af det 17. århundrede den kirkelige førstemand i kongens del af Sønderjylland, generalsuperintendent Stephan Klotz, der fremmede det højtyske sprog i kirken. Mens der i Mellemslesvig havde været præstedynastier som i Nordslesvig, blev denne tradition for Mellemslesvigs vedkommende nu brudt. Når Stephan Klotz foretrak højtysktalende præster, var det ikke mindst, fordi de delte hans særlige kirkelige opfattelse; dem måtte han hente udefra. Omkring 16501660-1670 kom i meget stort tal præster fra sydlige tyske egne til de dansktalende dele af Mellemslesvig. I Hanved havde slægten Brekling siddet $\mathbf{i}$ generationer; her var prædikensproget dansk. Stephan Klotz fortrængte under menighedens protest Frederik Brekling, men protesterne hjalp ikke, efterfølgeren blev en mand fra Rostock, som menigheden ikke forstod. Hele Flensborg amt fik efterhånden højtysk kirkesprog. Den kirkelige sproggrænse gik nu nord om Bov og Hanved sogne, og sådan var stillingen indtil 1850. 
I Kær herred i Tønder amt trængte det tyske sprog langsommere frem end i Flensborg amt. Det var gottorpsk område; her var traditionen stærkere; der var ikke noget sidestykke til en kirkens stridsmand som Stephan klotz. Der blev prædiket på dansk adskillige steder endnu i det 18 . ârh., men der var dog som helhed en tilbagegangslinie at spore. Stort set fæstnedes kirkesprogsgrænsen der, hvor nu statsgræensen gâr.

Det har her kun været formâlet at opstille en hypotese med hensyn til den kirkelige sproggrænses opståen. Den tilfældige linie tværs gennem landet er et af de mange besynderlige forhold $i$ den pá mærkværdigheder rige sønderjyske historie. Den vil også fortsat give anledning til overvejelser.

\section{NOTER OG HENVISNINGER}

1. Bd. III, s. 472 .

2. Slesvigs delte bispedomme 1948 , s. 144 .

3. Citatet Iyder $\mathbf{i}$ oversættelse silledes: "at vikaren på de enkelte aposteldage og større festdage samt pai sondagene skal prædike pä modersmalet for folket på et dertil egnet sted i kirken eller i Haderslev hys omegn".

C. M. A. Matthiesen: Aktstykker til Oplysning om Kannikecollegiet i Haderslev, s. 22.

4. Th. O. Achelis: Deutsche und dänische Gottesdienste im Herzogtum Schleswig. Schriften des Vereins für Schleswig-Holsteinische Kirchengeschichte. 2. Reihe 10. bd., s. 81 .

5. Th. O. Achelis giver $i$ den ovenfor citerede afhandling en del eksempler på sporadisk anvendelse af dansk prædikensprog syd for den nuværende grænse. 